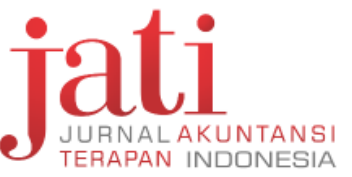

Jati: Jurnal Akuntansi Terapan Indonesia Vol 1 No 2 Hal 91-99 Oktober 2018

DATA ARTIKEL:

Diterima: 31 Juli 2018

Direviu: 7 Agustus 2018

Direvisi: 30 Oktober 2018

Disetujui: 31 Oktober 2018

TOPIK ARTIKEL:

Analisis Laporan Keuangan

ABSTRAK: Penelitian ini bertujuan untuk mengukur independensi pemerintah daerah dalam melaksanakan otonomi daerah di Kabupaten Sleman dengan menilai kinerja keuangan Badan Keuangan dan Aset Daerah (BKAD) berdasarkan Laporan Realisasi Anggaran (LRA) selama 5 tahun dari 2012-2016 dengan cara menganalisis rasio kemandirian keuangan regional, rasio efisiensi pembelian, analisis varian, tingkat desentralisasi, rasio ketergantungan keuangan regional, dan rasio cakupan layanan utang (DSC). Hasil penelitian menunjukkan bahwa pola hubungan kemandirian pemerintah daerah dianggap belum cukup independen, tetapi tingkat efisiensi pengelolaan keuangan dinilai efisien. Tingkat desentralisasi fiskal Kabupaten Sleman dianggap cukup karena realisasi pendapatan PAD sangat efektif, namun tingkat ketergantungan keuangan daerah terhadap pemerintah pusat dianggap sangat tinggi. Salah satu faktornya adalah karena kurangnya kontribusi dari Pajak Bumi dan Bangunan Pendapatan ke PAD. Situasi ini disebabkan oleh pendapatan Pajak Bumi dan Bangunan yang tidak efektif. Rasio partumbuhan menunjukkan bahwa kemampuan $\mathrm{Pe}$ merintah Kabupaten Sleman dalam mempertahankan dan meningkatkan keberhasilan berfluktuasi.

Kata Kunci: Rasio Kemandirian, Rasio Efektivitas, Kontribusi Pajak Bumi dan Bangunan

ABSTRACT: This research aims to measure the independence of regional government in practicing regional autonomy in Sleman Regency by assessing the

\section{Menilai Kinerja Keuangan dengan Analisis Rasio Keuangan: Studi Kasus BKAD Sleman}

\author{
http://journal.umy.ac.id/index.php/jati \\ (C) $2018 \mathrm{JATI}$. All rights reserved \\ DOI: 10.18196/jati.010210
}

\author{
DESI SUSILAWATI*, LINDA KUSUMASTUTI WARDANA, \\ INTAN FAJAR RAHMAWATI \\ Universitas Muhammadiyah Yogyakarta \\ *Email korespondensi: desisusilawati@umy.ac.id
}

the financial performance of The Regional Board of Finance and Asset (BKAD) based on the Budget Realization Report (LRA) for 5 years from 2012-2016 by analyzing the regional financial independence ratio, purchasing efficiency ratio, variants analysis, decentralization degree, regional financial dependency ratio, and debt service coverage ratio (DSCR). The result of this research shows that the relationship pattern of regional government independence is considered not independent enough, but the level of financial management efficiency is considered efficient. The degree of Sleman Regency fiscal decentralization is considered sufficient because the realization of PAD income is very effective, however the level of regional financial dependency toward central government is considered very high. One of the factors is due to lack of contribution from Land and Building Tax Income to PAD. This situation is caused by ineffective Land and Building Tax income. The growth ratio shows that the ability of Sleman Regency Government in maintaining and improving success fluctuates.

\section{Keywords: Self-Sufficiency Ratio, Effectiveness Ratio, Contri- bution Of Land and Building Tax}

SITASI ARTIKEL:

Susilawati, D., Wardana, L., K., \& Rahmawati, I., F. (2018). Kinerja Keuangan Dengan Financial Ratio Analisys: Studi Kasus Bkad Sleman. Jati: Jurnal Akuntansi Terapan Indonesia, 1(2), 9199.

\section{PENDAHULUAN}

Adanya otonomi daerah yang merupakan konsep pembangunan ekonomi berbasis desentralisasi pemerintahan daerah mempunyai wewenang seluas-luasnya untuk menyelenggarakan dan mengatur pemerintahan yang mencakup kewenangan seperti mengatur pembangunan daerah, memberikan pelayanan kepada masyarakat, dan mengatur urusan pemerintahan lainnya. Konsekuensi adanya otonomi daerah yaitu pemerintah daerah harus memiliki sumber keu- 
angan agar mampu memberikan kese-jahteraan dan pelayanan kepada masyarakat di daerahnya. Keberhasilan dalam penyelenggaraan otonomi daerah tidak terlepas dari kerja keras Pemerintah Daerah dalam mengelola keuangannya secara tertib dan taat pada peraturan perundang-undangan. Sedangkan menurut Halim (2011), ciri daerah berhasil melaksanakan otonomi adalah terletak pada kemampuan mengatur dan mengelola keuangan daerahnya. Penerapan otonomi daerah diharapkan agar daerah memiliki kemampuan menggali sumbersumber keuangan daerah, menggunakan, dan mengelola sumber keuangan dalam rangka membiayai urusan pemerintahan yang akan menentukan keberhasilan kebijakan otonomi daerah tersebut (Sanusi dan Irman, 2012). Disamping itu daerah otonom harus mampu mengoptimalkan potensi pendapatan daerah menjadi sumber keuangan terbesar dan mengupayakan seminimal mungkin ketergantungan pada bantuan pemerintah pusat.

Perimbangan antara pemerintah pusat dengan pemerintah daerah dapat dikatakan ideal apabila setiap tingkat pemerintahan dapat secara independen mengatur keuangannya untuk membiayai tugas dan wewenang daerahnya masing-masing (Dollery, 2009). Akuntabilitas merupakan salah satu bentuk pertanggungjawaban Pemda dalam bidang keuangan daerah. Hal ini diperlukan karena keuangan daerah merupakan salah satu unsur yang penting dalam menyelenggarakan pemerintahan dan pembangunan daerah (Lotz, 2005). Pelaksanaan otonomi daerah yang diterapkan di Indonesia adalah skema desentralisasi. Menurut Fitriani dan Dwirandra (2014) data APBD yang bersifat absolut belum sepenuhnya menyediakan kebutuhan informasi mengenai kinerja keuangan daerah. Skema desentralisasi fiskal yang digunakan dalam melaksanakan otonomi daerah ditengarai belum menunjang keberhasilan dalam melaksanakan otonomi daerah dan belum sepenuhnya mampu menggali sumber pendapatan daerah.

Menurut Adi dan Ekaristi (2009) seiring dengan berjalannya waktu tingkat kemandirian daerah tidak menunjukkan perkembangan yang berarti, namun justru mengalami penurunan. Penelitian yang dilakukan oleh Susilo dan Adi (2007) serta Setiaji dan Adi (2007) pada era otonomi tingkat kemandirian Pemerintah Daerah cenderung mengalami penurunan. Hal tersebut dikarenakan Pemerintah Daerah dalam pelaksanaan otonomi banyak yang tidak mengupayakan peningkatan Pendapatan Asli Daerah (PAD) namun cenderung semakin menggantungkan diri pada Dana Alokasi Umum (DAU). Padahal ciri utama bahwa daerah telah mampu melaksanakan otonomi adalah terletak pada kemampuan dalam mengelola keuangan daerah untuk mem- biayai penyelenggaraan pemerintah daerahnya dengan tingkat ketergantungan pada Pemerintah Pusat semakin kecil (Yanusa, 2013).

Dalam rangka mengetahui kinerja pemerintah daerah peneliti tertarik untuk mengkaji menggunakan analisis berbasis rasio. Disamping itu menurut Widodo (dalam Halim, 2011) analisis rasio telah banyak digunakan oleh lembaga perusahaan yang bersifat komersial sebagai alat analisis keuangan, berbeda dengan lembaga publik yaitu pemerintah daerah penggunaan analisis rasio masih sangat terbatas.

Hasil penelitian Vendra (2017) berdasarkan Rencana Pembangunan Jangka Menengah Daerah (RPJMD) Kabupaten Sleman 2011-2015, permasalahan yang dihadapi dalam pengelolaan keuangan daerah adalah potensi keuangan daerah belum tergali secara optimal. Harus diakui untuk APBD Kabupaten Sleman masih tergantung dengan besaran dana dari pemerintah pusat. Pelaksanaan otonomi daerah tidak dapat dipungkiri bahwa ketergantungan daerah terhadap pusat masih relatif tinggi. Pendapatan daerah masih didominasi oleh dana perimbangan. Sementara itu, kontribusi PAD terhadap pendapatan daerah, tercatat masih minim pada tahun 2015 realisasi PAD untuk APBD Kabupaten Sleman sebesar Rp 643.130.079.828,03 dana Perimbangan mencapai angka Rp 1.080.162.444.931,00.

Pemilihan Pemda Kabupaten Sleman sebagai objek penelitian karena berdasarkan data Realisasi Pendapatan dan Belanja Pemerintah Daerah di Daerah Istimewa Yogyakarta Tahun 2012 yang disajikan pada Tabel 1, Pemilihan Pemda Kabupaten Sleman sebagai objek penelitian, karena berdasarkan data Realisasi Pendapatan dan Belanja Pemerintah Daerah di Daerah Istimewa Yogyakarta Tahun 2012 Sleman merupakan kabupaten dengan realisasi Pendapatan Asli Daerah yang disajikan pada tabel, Kabupaten Sleman merupakan kabupaten dengan penerimaan keuangan terbesar diantara kabupaten/kota lainnya di Daerah Istimewa Yogyakarta yaitu mencapai nilai 1,59 trilyun rupiah. Kemudian pada tahun tersebut kabupaten ini mengalami surplus anggaran sebesar 168,32 milyar rupiah karena realisasi belanja sebesar 1,42 milyar rupiah.

Selain itu pemilihan Kabupaten Sleman didukung dengan adanya data menurut data Badan Statistik Daerah Istimewa Yogyakarta (BPS DIY) yang menyebutkan bahwa Kabupaten Sleman merupakan daerah yang memiliki Pendapatan Asli Daerah (PAD) yang terus menerus mengalami kenaikan dari tahun 2011-2015, yang disajikan pada Tabel 2. Menurut data tersebut realisasi PAD Kabupaten Sleman meningkat dari 17,29 persen pada tahun 2011 menjadi 28,03 persen pada tahun 2015. 
Tabel 1. Realisasi Pendapatan dan Belanja Pemerintah Daerah di Daerah Istimewa Yogyakarta Tahun 2012

\begin{tabular}{lcrrr}
\hline Pemerintah Daerah & $\begin{array}{c}\text { Realisasi } \\
\text { Pendapatan } \\
\text { (Juta Rupiah) }\end{array}$ & $\begin{array}{c}\text { Realisasi Belanja } \\
\text { (Juta Rupiah) }\end{array}$ & $\begin{array}{c}\text { Surplus/ } \\
\text { Defisit } \\
\text { (Juta Rupiah) }\end{array}$ & $\begin{array}{c}\text { Ratio } \\
\text { Pendapatan } \\
\text { terhadap } \\
\text { Belanja }\end{array}$ \\
\hline \multicolumn{1}{c}{$(1)$} & $(2)$ & $(3)$ & \multicolumn{1}{c}{$(4)$} & $(5)$ \\
\hline D. I. Yogyakarta & $2.171 .7234,31$ & $2.053 .825,96$ & $117.908,35$ & 1,06 \\
Kab. Kulonprogo & $882.586,66$ & $881.690,25$ & 896,41 & 1,00 \\
Kab. Bantul & $1.337 .570,72$ & $1.282 .878,38$ & $54.692,34$ & 1,04 \\
Kab. Gunungkidul & $1.076 .502,00$ & $1.073 .158,31$ & $3.343,69$ & 1,00 \\
Kab. Sleman & $1.589 .722,97$ & $1.421 .401,17$ & $168.321,80$ & 1,12 \\
Kota Yogyakarta & $1.158 .134,80$ & $1.023 .949,92$ & $134.184,88$ & 1,13 \\
\hline
\end{tabular}

Sumber: Badan Pusat Statistik Yogyakarta (http://yogyakarta.bps.go.id)

Tabel 2. Realisasi Pendapatan Asli Daerah (PAD), serta Persentasenya terhadap Pendapatan dan Belanja Pemerintah Daerah di Daerah Istimewa Yogyakarta 2015

\begin{tabular}{lccccc}
\hline \multicolumn{1}{c}{ Pemerintah Daerah } & 2011 & 2012 & 2013 & 2014 & 2015 \\
\hline \multicolumn{1}{c}{$(1)$} & $(2)$ & $(3)$ & $(4)$ & $(5)$ & $(6)$ \\
\hline D. I. Yogyakarta & 54,02 & 46,23 & 38,87 & 46,65 & 46,86 \\
Kab. Kulonprogo & 6,79 & 8,39 & 9,57 & 14,16 & 13,92 \\
Kab. Bantul & 10,92 & 12,46 & 14,75 & 19,70 & 20,02 \\
Kab. Gunungkidul & 5,64 & 6,23 & 6,72 & 11,60 & 12,26 \\
Kab. Sleman & 17,29 & 18,94 & 23,65 & 27,61 & 28,03 \\
Kota Yogyakarta & 24,05 & 29,26 & 29,25 & 32,24 & 35,60 \\
\hline
\end{tabular}

Sumber: Badan Pusat Statistik Yogyakarta (http://yogyakarta.bps.go.id)

Hasil penelitian ini diharapkan dapat menjadi aspirasi bagi daerah lain untuk lebih meningkatkan kinerja dan kemandirian di sektor keuangan daerah melalui Pendapatan Asli Daerah yang salah satunya bersumber dari pajak Bumi dan Bangunan. Mengenai hal tersebut diharapkan PAD harus menjadi kontribusi terbesar dalam mobilisasi dana penyelenggaraan Pemda.

Penelitian ini diharapkan dapat menambah wawasan dan ilmu pengetahuan dalam bidang akuntansi tentang pemahaman analisis kinerja keuangan untuk publik khususnya pada BKAD Kabupaten Sleman. Hasil dari penelitian ini diharapkan dapat dipergunakan sebagai bahan masukan dalam melakukan perbaikan bagi BKAD Kabupaten Sleman terutama dalam meningkatkan kinerja keuangan. Penelitian ini juga diharapkan menjadi bahan evaluasi dan informasi dan Transfer Knowledge bagi pembuat kebijakan instansi yang berkaitan. Disamping itu hasil penelitian ini dapat dipergunakan sebagai bahan referensi atau acuan untuk melakukan penelitian selanjutnya, khususnya tentang analisis kinerja keuangan.

\section{METODE PENELITIAN}

Analisis data pada penelitian ini adalah deskriptif kuantitatif. Langkah pertama adalah dengan melakukan perhitungan rasio terhadap data ke- uangan yang diperoleh. Kemudian data tersebut dianalisis sesuai teori dalam sumber tertulis dan dideskripsikan dalam bentuk kalimat maupun gambar sehingga dapat memberikan penjelasan kinerja keuangan yang realistis dan sistematis. Adapun analisis yang akan digunakan:

\section{Rasio Kemandirian Keuangan Daerah}

Rasio ini dapat digunakan untuk menilai kemandirian keuangan pemerintah daerah dalam rangka membiayai pembangunan, pelayanan kepada masyarakat, dan urusan pemerintahan lainnya. Rasio Kemandirian Keuangan Daerah (RKKD) ditunjukkan oleh besar kecilnya PAD dibandingkan pendapatan daerah yang berasal dari sumber lain (Pendapatan Transfer) (Halim, 2011: L-5). Sedangkan pola hubungan dan tingkat kemandirian daerah diperlihatkan dalam Tabel 3.

\section{Rasio Efisiensi Belanja}

Rasio efisiensi belanja bertujuan mengukur tingkat penghematan anggaran oleh pemerintah daerah. Rasio ini dapat diperoleh dengan membandingkan realisasi belanja dengan anggaran belanja.

\section{Analisis Varians (selisih) anggaran pendapatan}

Analisis varians (selisih) anggaran pendapatan dilakukan dengan cara menghitung selisih an- 
tara realisasi pendapatan pemerintah daerah dengan estimasi. Suatu daerah dipandang mempunyai kinerja yang baik jika pemerintah daerah mampu memperoleh pendapatan yang melebihi jumlah yang dianggarkan. Sebaliknya apabila realisasi pendapatan yang melebihi jumlah yang dianggarkan, maka hal itu dinilai kurang baik. Apabila target pendapatan dapat dicapai bahkan terlampaui, maka hal itu tidak terlalu mengejutkan karena memang seharusnya demikian. Tetapi jika target pendapatan tidak tercapai, hal ini butuh penelaahan lebih lanjut terkait dengan penyebab tidak tercapainya target.

\section{Derajat Desentralisasi}

Derajat Desentralisai (DD) menggambarkan tingkat kontribusi Pendapatan Asli Daerah (PAD) terhadap total penerimaan daerah (total PD). Rasio ini dapat diperoleh dengan membandingkan PAD dengan total PD. Semakin tinggi kontribusi PAD maka semakin tinggi kemampuan pemerintah daerah dalam penyelenggaraan desentralisasi. Sedangkan kriteria penilaian tingkat derajat desentralisasi dicantumkan pada Tabel 4.

\section{Rasio Ketergantungan Keuangan Daerah}

Rasio ketergantungan keuangan daerah menunjukkan tingkat ketergantungan pemerintah daerah terhadap pemerintah pusat. Rasio ini di dapat dengan pendapatan transfer dibagi total pendapatan daerah. Semakin tinggi rasio ini maka semakin besar tingkat ketergantungan pemerintah daerah terhadap pemerintah pusat. Sedangkan nilai kriteria penilaian ketergantungan keuangan daerah dapat dilihat di Tabel 5 .

\section{Debt Service Coverage Ratio (DSCR)}

Pemerintah Daerah dalam menyelenggarakan otonomi daerah disamping mengandalkan PAD, pemerintah daerah dapat menggunakan alternatif sumber dana lain. Sumber dana lain bisa berasal dari pinjaman yang dilakukan sesuai dengan prosedur dan peraturan yang berlaku (Halim, 2011). DSCR didapatkan dengan menambahkan nilai pendapatan asli daerah (PAD), Bagian Daerah (BD) dari Pajak Bumi dan Bangunan (PBB) dan Bea Perolehan Hak atas Tanah dan Bangunan (BPHTB), penerimaan lainnya, dan Dana Alokasi Umum (DAU) kemudian dikurangi dengan Belanja Wajib (BW). Hasilnya kemudian dibagi dengan total pokok angsuran ditambah bunga dan biaya pinjaman.

\section{HASIL DAN PEMBAHASAN}

Analisis Keuangan Daerah BKAD Kabupaten Sleman dalam penelitian ini adalah suatu proses penilaian kinerja BKAD serta penilaian menegenai tingkat kemajuan pencapaian pelaksanaan pekerjaan/kegiatan BKAD Kabupaten Sleman pada tahun 2012-2016. Analisis yang digunakan untuk melakukan penilaian tersebut yaitu menggunakan analisis Rasio Kinerja Keuangan Daerah. Beberapa rasio yang dapat digunakan yaitu: analisis rasio kemandirian keuangan daerah, rasio efisiensi belanja, analisis varians (selisih) anggaran pendapatan, derajat desentralisasi, rasio ketergantungan keuangan daerah, Debt Service Coverage Ratio (DSCR). Data yang digunakan dalam melakukan penelitian ini adalah Laporan Realisasi Anggaran Pemerintah Daerah Kabupaten Sleman Tahun 2012-2016.

Tabel 3. Pola Hubungan dan Tingkat Kemandirian Daerah

\begin{tabular}{ccc}
\hline No & Presentase & Kategori \\
\hline 1 & $00,00 \%-25 \%$ & Rendah Sekali \\
2 & $25,00 \%-50 \%$ & Rendah \\
3 & $50,00 \%-75 \%$ & Sedang \\
4 & $75,00 \%-100 \%$ & Tinggi \\
\hline Sumber: Abdul Halim, 2001 (dalam Hanik E Karyanti, 2014).
\end{tabular}

Tabel 4. Kriteria Penilaian Tingkat Derajat Desentralisasi

\begin{tabular}{ccc}
\hline No & Presentase & Kategori \\
\hline 1 & $00,00 \%-10 \%$ & Sangat Kurang \\
2 & $10,01 \%-20 \%$ & Kurang \\
3 & $20,01 \%-30 \%$ & Cukup \\
4 & $30,01 \%-40 \%$ & Sedang \\
5 & $40,01 \%-50 \%$ & Baik \\
6 & $>50,00 \%$ & Sangat Baik \\
\hline
\end{tabular}

Sumber: Tim Litbang Depdagri-Fisipol UGM, 1991 (dalam Wahyu, 2015).
Tabel 5. Kriteria Penilaian Ketergantungan Keuangan Daerah

\begin{tabular}{ccc}
\hline No & Presentase & Kategori \\
\hline 1 & $00,00 \%-10 \%$ & Sangat Kurang \\
2 & $10,01 \%-20 \%$ & Kurang \\
3 & $20,01 \%-30 \%$ & Cukup \\
4 & $30,01 \%-40 \%$ & Sedang \\
5 & $40,01 \%-50 \%$ & Baik \\
6 & $>50,00 \%$ & Sangat Baik
\end{tabular}

Sumber: Tim Litbang Depdagri-Fisipol UGM, 1991 (dalam Wahyu, 2015). 


\section{Rasio Kemandirian Keuangan Daerah (RKKD)}

RKKD ditunjukkan oleh besar kecilnya PAD dibandingkan pendapatan daerah yang berasal dari sumber lain. Hasil dari perhitungan analisis rasio kemandirian keuangan daerah dapat dilihat dari Tabel 6.

Diketahui Rasio Kemandirian Keuangan Daerah Kabupaten Sleman pada tahun 2012 yaitu sebesar $23,49 \%$ merupakan tahun terendah pada 5 tahun terakhir dan rasio tertinggi yaitu pada tahun 2016 yaitu sebesar 44,74\%. Rata-rata kemandirian dikatagorikanmasih kurang karena baru mencapai 35,34\%. Namun Rasio Kemandirian Keuangan Daerah Kabupaten Sleman mengalami peningkatan dari tahun ke tahun. Rasio kemandirian yang masih kurang mandiri mengakibatkan kemampuan keuangan Daerah Kabupaten Sleman dalam membiayai pelaksanaan pemerintah dan pembangunan daerah masih bergantung bantuan pada Pemerintah Pusat. Faktor lain yaitu disebabkan oleh penerimaan PBB yang merupakan salah satu komponen yang mampu meningkatkan PAD belum efektif dan belum dikelola secara maksimal. Hal tersebut terlihat dari perhitungan rata-rata efektivitas penerimaan PBB tahun 2015-2016 yaitu sebesar 78,64\%.

\section{Rasio Efisiensi Belanja}

Rasio efisiensi belanja bertujuan mengukur tingkat penghematan anggaran oleh pemerintah daerah. Rasio ini dapat diperoleh dengan membandingkan realisasi belanja dengan anggaran belanja. Hasil dari perhitungan analisis Rasio Efisiensi Belanja dapat dilihat dari Tabel 7.

Dari tabel diatas dapat dilihat bahwa rasio efisiensi belanja Kabupaten Sleman dalam rangka melakukan penghematan anggaran oleh Pemerintah Kabupaten Sleman sudah cukup Efisien. Hal tersebut dapat dilihat dari rata-rata efisiensi belanja dari tahun 2012-2016 yaitu sebesar 87,15 termasuk kedalam katagori cukup efisien. Rasio efisiensi belanja tertinggi pada tahun 2016 yaitu 92,73 persen dengan kategori kurang efisien. Karena semakin tinggi hasil perhitungan rasio efisiensi belanja menandakan semakin inefisiensi suatu Pemerintah Daerah dalam menghemat anggarannya. Atau dapat dikatakan belanja telalu besar.

\section{Analisis Varians (selisih) anggaran pendapatan}

Analisis ini dilakukan dengan cara menghitung selisih antara realisasi pendapatan pemerintah daerah dengan estimasi. Suatu daerah dipandang mempunyai kinerja yang baik jika pemerintah daerah mampu memperoleh pendapatan yang melebihi jumlah yang dianggarkan. Sebaliknya apabila realisasi pendapatan yang melebihi jumlah yang dianggarkan, maka dinilai kurang baik.

\section{Derajat Desentralisasi}

Derajat Desentralisai (DD) menggambarkan tingkat kontribusi PAD terhadap total penerimaan daerah. Hasil dari perhitungan Derajat Desentralisasi ditunjukkan pada Tabel 9.

Diketahui Derajat Desentralisasi Kabupaten Sleman pada tahun 2012 yaitu sebesar 18,94\% merupakan tahun terendah pada 5 tahun terakhir dan rasio tertinggi yaitu pada tahun 2016 yaitu se-besar 30,79\%. Rata-rata Derajat Desentralisasi dikategorikan sedang karena telah mencapai $25,80 \%$. Menurut perhitungan Derajat Desentralisasi, Peme-rintah Daerah Kabupaten Sleman dapat dikatakan mengalami peningkatan dalam penyelenggarakan desentralisasi. Hal tersebut terlihat dari rasio derajat desentralisasi yang dari tahun ke tahun meningkat dari katagori kurang hingga mencapai katagori se-dang. Namun masih perlu dilakukan peningkatan karena rata-rata dalam lima tahun terakhir masih dalam katagori cukup.

\section{Rasio Ketergantungan Keuangan Daerah}

Rasio ketergantungan keuangan daerah menunjukkan tingkat ketergantungan pemerintah daerah terhadap pemerintah pusat. Hasil dari perhitungan Rasio Ketergantungan Keuangan Daerah dapat dilihat dari Tabel 10.

Diketahui Rasio Ketergantungan Keuangan Daerah Kabupaten Sleman pada tahun 2012 yaitu sebesar $80,62 \%$ merupakan tahun dengan rasio tertinggi pada 5 tahun terakhir dan rasio terendah yaitu pada tahun 2016 yaitu sebesar $68,82 \%$. Ratarata Rasio Ketergantungan Keuangan Daerah dikatagorikan sangat tinggi karena mencapai $73,86 \%$. Menurut perhitungan Rasio Ketergantungan Keuangan Daerah, Pemerintah Daerah Kabupaten Sleman dapat dikatakan masih sangat bergantung pada pemerintah pusat. Total Pendapatan Daerah masih banyak yang berasal dari pendapatan trans-fer. Hal tersebut menandakan bahwa Pemerintah Daerah Kabupaten Sleman belum mampu memaksimalkan Pendapatan Asli Daerah dalam mempero-leh Pendapatan Daerah.

\section{Debt Service Coverage Ratio (DSCR)}

Pemerintah Daerah dalam menyelenggarakan otonomi daerah disamping mengandalkan PAD, pemerintah daerah dapat menggunakan alternatif sumber dana lain. DSCR mengindikasikan kelayakan pemerintah daerah untuk melakukan pinjaman. DSCR ditetapkan minimal 2,5\% sesuai dengan Pasal 16 ayat (2) Undang-Undang Nomor 30 Tahun 
201 tentang Pinjaman Daerah. Dari Tabel 11 dapat dilihat bahwa Kabupaten Sleman telah memenuhi kriteria yang ditentukan sehingga layak apabila akan melakukan pinjaman baik jangka pendek ataupun panjang saat terjadi defisit anggaran. Adanya pengenaan pajak final tersebut menyebabkan timbulnya perbedaan besarnya pajak terutang yang disetorkan sebelum maupun sesudah revaluasi aset tetap. Kebijakan revaluasi aset tetap yang dilakukan oleh perusahaan pada periode 2017 dapat dikatakan belum berhasil dalam upaya penghematan beban pajak penghasilan. Hal tersebut dikarenakan meningkatnya beban pajak yang harus disetor oleh perusahaan, yang mana saat sebelum melakukan revaluasi aset tetap beban pajak yang harus diba-yarkan sebesar USD 8.425.842, sedang-kan setelah melakukan revaluasi aset sebesar USD 57.113.436. Karena PT Garuda Indonesia (Persero) Tbk hanya melakukan pada beberapa aset tetap saja atau sering disebut dengan revaluasi parsial.

Tabel 6. Perhitungan Rasio Kemandirian Keuangan Daerah

\begin{tabular}{ccccc}
\hline Tahun & Realisasi PAD & Pendapatan Transfer & Rasio & Keterangan \\
\hline 2012 & $301.069 .539 .282,13$ & $1.281 .708 .216 .150,00$ & 23,49 & Kurang \\
2013 & $449.270 .304 .864,83$ & $1.442 .483 .146 .251,00$ & 31,15 & Kurang \\
2014 & $573.337 .599 .560,11$ & $1.499 .148 .394 .633,50$ & 38,24 & Kurang \\
2015 & $643.130 .079 .828,03$ & $1.646 .360 .587 .532,09$ & 39,06 & Kurang \\
2016 & $717.151 .176 .028,57$ & $1.602 .998 .761 .228,23$ & 44,74 & Kurang \\
\hline \multicolumn{5}{r}{ Rata-Rata } \\
\hline
\end{tabular}

Sumber: Data diolah (2018)

Tabel 7. Perhitungan Rasio Efisiensi Belanja

\begin{tabular}{ccccc}
\hline Tahun & Anggaran Belanja Daerah & Realiasasi Belanja Daerah & Rasio & Keterangan \\
\hline 2012 & $1.595 .739 .879 .570,00$ & $1.421 .401 .170 .875,33$ & 89,07 & Cukup Efisien \\
2013 & $1.946 .380 .363 .064,13$ & $1.693 .528 .297 .005,79$ & 87,01 & Cukup Efisien \\
2014 & $2.288 .645 .856 .460,56$ & $1.896 .477 .377 .488,36$ & 82,86 & Cukup Efisien \\
2015 & $2.770 .882 .731 .330,03$ & $2.328 .751 .919 .925,33$ & 84,04 & Cukup Efisien \\
2016 & $2.647 .865 .812 .373,38$ & $2.455 .446 .948 .874,20$ & 92,73 & Kurang Efisien \\
\hline \multicolumn{7}{c}{ Rata-Rata } & 87,15 & Cukup Efisien \\
\hline
\end{tabular}

Sumber: Data diolah (2018)

Tabel 8. Perhitungan Analisis Varians

\begin{tabular}{cccc}
\hline Tahun & Anggaran Pendapatan & Realisaasi Pendapatan Daerah & Rasio Analisis Varians \\
\hline 2012 & $1.475 .128 .477 .847,31$ & $1.589 .722 .974 .409,13$ & $114.594 .496 .561,82$ \\
2013 & $1.768 .438 .488 .349,11$ & $1.899 .525 .636 .838,83$ & $131.087 .148 .489,72$ \\
2014 & $1.969 .264 .200 .317,70$ & $2.076 .820 .131 .084,13$ & $107.555 .930 .766,43$ \\
2015 & $2.262 .230 .417 .718,80$ & $2.294 .622 .764 .756,12$ & $32.392 .347 .037,32$ \\
2016 & $2.183 .747 .824 .232,36$ & $2.329 .097 .456 .006,80$ & $145.349 .631 .774,44$ \\
\hline Rata-Rata & $1.931 .761 .881 .693,06$ & $2.037 .957 .792 .619,00$ & $106.195 .910 .925,95$ \\
\hline
\end{tabular}

Sumber: Data diolah (2018)

Tabel 9. Perhitungan Derajat Desentralisasi

\begin{tabular}{|c|c|c|c|c|}
\hline Tahun & $\begin{array}{c}\text { Total Realisasi Pendapatan } \\
\text { Daerah }\end{array}$ & Realisasi PAD & $\begin{array}{l}\text { Rasio Derajat } \\
\text { Desentralisasi }\end{array}$ & Keterangan \\
\hline 2012 & $1.589 .722 .974 .409,13$ & $301.069 .539 .284,13$ & 18,94 & Kurang \\
\hline 2013 & $1.899 .525 .636 .838,83$ & $449.270 .304 .864,83$ & 23,65 & Cukup \\
\hline 2014 & $2.076 .820 .131 .084,13$ & $573.337 .599 .560,11$ & 27,61 & Cukup \\
\hline 2015 & $2.294 .622 .764 .756,12$ & $643.130 .079 .828,03$ & 28,03 & Cukup \\
\hline 2016 & $2.329 .097 .456 .006,80$ & $717.151 .176 .028,57$ & 30,79 & Sedang \\
\hline \multicolumn{3}{|c|}{ Rata-Rata } & 25,80 & Cukup \\
\hline
\end{tabular}

Sumber: Data diolah (2018) 
Tabel 10. Perhitungan Rasio Ketergantungan Keuangan Daerah

\begin{tabular}{ccccc}
\hline Tahun & $\begin{array}{c}\text { Total Realisasi Pendapatan } \\
\text { Daerah }\end{array}$ & Pendapatan Transfer & $\begin{array}{c}\text { Rasio Ketergantungan } \\
\text { Keuangan Daerah }\end{array}$ & Keterangan \\
\hline 2012 & $1.589 .722 .974 .409,13$ & $1.281 .708 .216 .150,00$ & 80,62 & Sangat Tinggi \\
2013 & $1.899 .525 .636 .838,83$ & $1.442 .483 .146 .251,00$ & 75,94 & Sangat Tinggi \\
2014 & $2.076 .820 .131 .084,13$ & $1.499 .148 .394 .633,50$ & 72,18 & Sangat Tinggi \\
2015 & $2.294 .622 .764 .756,12$ & $1.646 .360 .587 .532,09$ & 71,75 & Sangat Tinggi \\
2016 & $2.329 .097 .456 .006,80$ & $1.602 .998 .761 .228,23$ & 68,82 & Sangat Tinggi \\
\hline \multicolumn{6}{r}{ Rata-Rata } & & 73,86 & Sangat Tinggi \\
\hline
\end{tabular}

Sumber: Data diolah (2018)

Tabel 11. Perhitungan DSCR BKAD Kabupaten Sleman Tahun 2012-2016

\begin{tabular}{lrrrrr}
\multicolumn{1}{c}{ Keterangan } & \multicolumn{1}{c}{$\begin{array}{c}\text { 2012 } \\
\text { (Ribuan) }\end{array}$} & $\begin{array}{c}\text { 2013 } \\
\text { (Ribuan) }\end{array}$ & \multicolumn{1}{c}{$\begin{array}{c}\text { 2014 } \\
\text { (Ribuan) }\end{array}$} & \multicolumn{1}{c}{$\begin{array}{c}\text { 2015 } \\
\text { (Ribuan) }\end{array}$} & \multicolumn{1}{c}{$\begin{array}{c}\text { 2016 } \\
\text { (Ribuan) }\end{array}$} \\
\hline PAD & 301.069 .539 & 449.270 .304 & 573.337 .599 & 643.130 .079 & 717.151 .176 \\
DHB Pajak/Bukan Pajak & 211.375 .515 & 184.821 .149 & 210.865 .585 & 79.383 .739 & 110.089 .918 \\
DAU & 795.708 .767 & 891.589 .912 & 952.102 .502 & 984.410 .612 & 1.014 .310 .630 \\
Belanja Wajib & 979.253 .621 & 1.034 .255 .811 & 1.110 .060 .035 & 1.197 .522 .434 & 1.263 .367 .532 \\
Bunga & 45.273 & 28.750 & 12.341 & 258.765 & 3.021 .102 \\
Pokok Angsuran & 137.744 & 137.744 & 137.744 & 0 & 7.020 .000 \\
\hline DSCR & $\mathbf{1 7 9 7 1 0 , 1 9 0 9}$ & $\mathbf{2 9 5 1 6 1 , 1 1 9 3}$ & $\mathbf{4 1 7 2 6 0 , 6 5 3}$ & $\mathbf{1 9 6 8 5 8 , 9 2 4 5}$ & $\mathbf{5 7 5 8 , 1 7 4 6 7}$ \\
\hline
\end{tabular}

Sumber: Laporan Realisasi Anggaran BKAD Kab. Sleman, 2018 (telah diolah kembali)

\section{KESIMPULAN DAN SARAN}

Hasil analisis dan pembahasan yang telah diuraikan rata-rata kinerja keuangan BKAD Kabupaten Sleman sudah cukup baik. Pola hubungan tingkat kemandirian Pemda tergolong kurang mandiri yaitu sebesar 35,34\%, namun tingkat efisien belanja dae-rah sudah cukup efisien yaitu sebesar 87,15\%. Ting-kat Derajat Desentralisasi Fiskal Pemda Kabupaten Sleman sudah cukup yaitu sebesar 25,80 karena realisasi penerimaan PAD sangat efektif sebesar $119,71 \%$, namun tingkat ketergantungan keuangan daerah terhadap pemerintah pusat tergolong sangat tinggi yaitu sebesar $73,86 \%$. Berdasarkan analisis rasio Kabupaten Sleman apabila mengalami defisit anggaran telah layak dan mampu melakukan pinjaman karena DSCR sudah melebihi $2,5 \%$.

Badan Keuangan dan Aset Daerah diharapkan terus menggali potensi-potensi yang masih ada di Kabupaten Sleman. Faktor yang mempengaruhi peningkatan kinerja keuangan BKAD Kabupaten Sleman yaitu peningkatan kompetensi petugas/pegawai, meningkatkan kapasitas sumber daya pegawai, tingkat sarana dan prasarana operasional, peningkatan intensifikasi PAD, peningkatan sosialisasi peraturan daerah tentang kemitraan dan sisi pendapatan, peningkatan manajemen keuangan yang akuntabel, dan dengan peningkatan kualitas pelayanan publik.

\section{DAFTAR PUSTAKA}

Adi, H. \& Ekaristi, D. (2009). Fenomena Ilusi Fiskal dalam Kinerja Anggaran Pemda. Jurnal Keuangan dan Akuntansi Indonesia, 6(1).

Dollery, B. (2009). Local Government Reform and LocalGovernment Finance. Journal of New England University.

Fitriani, N., L., P. \& Dwirandra A.A.N.B. (2014). Penilaian Kinerja Keuangan Daerah Kabupaten/Kota di Provinsi Bali Tahun 20072011. E-Jurnal Akuntansi Universitas Udayana 8.1 (2014):211-227

Halim, A., et al. (2011). Akuntansi Keuangan Daerah. Jakarta: Salemba Empat.

Halim \& M. S., K. (2014). Teori, Konsep, dan Aplikasi Akuntansi Sektor Publik. Jakarta: Salemba Empat.

Lotz, J. (2005). Accountability and Control in the Financing of Local Government in Denmark. OECD Journal on Budgeting, 5(2).

Pemerintah Kabupaten Sleman. Tersedia: www.slemankab.go.id. (diakses 15 Mei 2018 pukul 22.17)

Peraturan Menteri Dalam Negeri No.13 Tahun 2006 tentang Pedoman Pengelolaan Keuangan Daerah.

Vendra, R. (2017). Analisis Kinerja Keuangan Daerah pada Pemerintag Daerah Kabupaten Bantul.Tugas Akhir, Sekolah Vokasi Universitas Gadjah Mada.

Wahyu, G. (2015). Analisis Kinerja Keuangan Pemerintah Daerah Istimewa Yogykarta. Tugas Akhir,Sekolah Vokasi Universitas Gadjah Mada. 
Yanusa, A., B., I. (2013). Assessment of Financial Performance of Ankpa Local Government Council of Kogi State. Journal of Kogi State University, Nigeria. 